\title{
Study of Genetic Variability, Heritability and Genetic Advance for Various Yield and Quality Traits in Sugarcane Genotypes (Saccharum officinarum)
}

\author{
Deepankar Pandey ${ }^{*}$, S.P. Singh, A.S. Jeena, K.A. Khan, Tabassum, \\ Arvind Negi and Deepak Koujalagi \\ Department of Genetics and Plant Breeding, College of Agriculture, Govind Ballabh Pant \\ University of Agriculture and Technology, Pantnagar, U.S. Nagar, 263145, \\ Uttarakhand, India \\ *Corresponding author
}

\section{A B S T R A C T}

\section{Keywords \\ Sugarcane, Genetic variability, Broad sense heritability, Genetic advance \\ Article Info \\ Accepted: \\ 12 March 2018 Available Online: 10 April 2018}

\begin{abstract}
Study of mean performance, genotypic coefficient of variation, phenotypic coefficient of variation, heritability in broad sense and genetic advance was done using fourteen sugarcane genotypes. These genotypes were tested in randomised block design with four replications. Genotypes significantly differed for all the 13 traits studied indicating sufficient variability was present in the experimental material and the present variability was found heritable for commercial cane sugar Percent, followed by germination Percent, brix percent, polarity value, sucrose content, number of millable canes and number of tillers. Both GCV and PCV estimates were found to be moderate for Germination Percent and Moderate values of genetic advance as percent mean were observed for germination Percent, commercial cane sugar Percent, commercial cane sugar yield, brix percent, polarity value and sucrose content.
\end{abstract}

\section{Introduction}

Sugarcane is a major crop of tropical and subtropical regions of the world which is cross pollinated, grown as an important cash crop and is a sucrose storing member of tall growing perennial monocotyledonous grasses. It belongs to the family Poaceae, tribe Andropogoneae, sub tribe Saccaharinineae and genus Saccharum (Tyagi and Lal, 2005). S. officinarum, S. barberi and S. sinense are three recognized cultivated species and $S$. spontaneum and $S$. robustum are two wild species of sugarcane. S. officinarum is an octaploid with $\mathrm{x}=10$ and $2 \mathrm{n}=80$ chromosome and is most widely cultivated species of sugarcane. Varieties of sugarcane are complex poly-ploids and their chromosome number varies from $2 \mathrm{n}=100$ to 120 or more (Prince, 1963). India is the second largest producer of sugarcane in the world after Brazil. Across the world, 70 per cent sugar is manufactured from sugarcane and it is a major source of raw material for sugar industries and other allied group of by product industries. It is grown in 5.34 million hectare with total production of 345.6 Million tones and productivity of 64.7 tonnes/ha (Indian Sugar, 2014). 
In any breeding programme, it is important to make choice of parents very carefully. Since, yield is a complex polygenic trait which influenced greatly by the environmental fluctuations, direct selection for yield may produce misleading results. Therefore, knowledge on various genetic variability parameters is crucial, much valuable and play important role for shaping new varieties.

Commercially cultivated sugarcane varieties are heterozygous and complex polyploids resulted in generation of great amount of genetic variability. It is important to divide the present variability into its heritable and nonheritable components with the help of suitable genetic parameters such as phenotypic and genotypic coefficient of variations, heritability estimates, and genetic advance under selection (Singh et al., 2015). Genotypic coefficient of variability gives the magnitude of genetic variance present in the population. Heritability denotes the proportion of phenotypic variance that is due to genotype, i.e., heritable and is act as a tool to predict the gain from selection in a population i.e., genetic advance. Genetic advance is also important as it indicates the magnitude of the expected genetic gain from one cycle of selection (Hamdi, 1992).

However, heritability estimates together with genetic advance are more important to predict the resulting effect of selecting the best individuals (Johnson et al., 1955). The information on the nature and the magnitude of variability present in the genetic material is of prime importance for a breeder to initiate any effective selection program. Coefficients of variation along with heritability as well as genetic advance are very essential to improve any trait of sugarcane because this would help in knowing whether or not the desired objectives can be achieved from the material (Tyagi and Singh, 1998). Therefore, present investigation was conducted to evaluate the degree of genetic variability, heritability and genetic advance in different sugarcane genotypes for better cane yield, sugar yield and its attributes

\section{Materials and Methods}

The experimental materials for present investigation consisted of fourteen sugarcane genotypes. Out of those genotypes, four were female lines, two were testers and eight were their F1s. All the genotypes are presented in Table 1. The crosses for the investigation were made in National Hybridization Garden at Sugarcane Breeding Institute; Coimbatore Tamil Nadu. These genotypes were tested in randomised block design with four replications at the Sugarcane Breeding Experimental Block of Norman Borlaug Crop Research Centre, Govind Ballabh Pant University of Agriculture and Technology, Pantnagar, U. S. Nagar, Uttarakhand. The biometrical observations were recorded for eight morphological traits viz., Germination per cent, Number of Tillers/h, Number of Millable Canes/h, Cane height, Cane thickness, Single Cane weight, Cane yield/h, Commercial cane sugar (CCS) yield/h and five quality traits viz., Juice Brix per cent, Juice Polarity Value, Juice sucrose per cent, Juice purity per cent and Commercial cane sugar per cent (CCS per cent). To test the significance of differences between treatments, analysis of variance was done as suggested Gomez and Gomez (1984). Genotypic coefficient of variation (GCV) and phenotypic coefficient of variation (PCV) were calculated according to Singh and Chaudhary (1985). Broad sense heritability values were calculated by using formula given by Falconer et al., (1996). The expected genetic advance for the different traits was estimated as suggested by Allard (1960), Singh and Chaudhary (1985) and Genetic advance as per cent of mean for each character was calculated as suggested by Johnson, Robinson and Comstock (1955).

\section{Results and Discussion}


The analysis of variance revealed that estimates of mean squares were found significant for all the characters except purity per cent indicating the presence of considerable diversity in the material under study (Table 2). Mean performance of genotypes presented in (Table 3). Among the parents, the superiority of Co Pant 97222 (T2) revealed by per se performance which recorded high mean values for eleven traits namely, Germination per cent, number of millable canes, cane height, cane diameter, single cane weight, Brix per cent, Polarity value, sucrose content, Commercial cane sugar per cent, Cane yield and Commercial cane sugar yield. The line Co Pant 98224 (L3) was recorded with high mean values for remaining two traits namely, tillers and purity per cent.

Therefore, Co Pant 97222 (T2) and Co Pant 98224 (L3) could be considered as desirable parents to use in hybridization programmes to improve sugarcane yield. Per se performance of hybrids can be used as a useful index for evaluation of the hybrids (Nadaraja, 1986). The mean performance is the primary criterion to evaluate the merit of hybrids. Among the hybrids, performance of Co Pant 94213 X CoSe 92423 (L1XT1) was better based on the mean values for traits Germination per cent, tillers count, cane dia-meter and single cane weight. Co Pant 84212 X Co Pant 97222 (L4XT2) performed better for the traits Polarity value, sucrose content, commercial cane sugar per cent and Commercial cane sugar yield. For number of millable canes and Cane yield highest mean values were given by Co Pant 94213 X Co Pant 97222 (L1XT2), for cane height and Brix per cent by Co Pant 98224 X CoSe 92423 (L3XT1) and for purity per cent by Co Pant 99213 X CoSe 92423 (L2XT1). Co Pant 94213 (L1) performed better with CoSe 92423 (T1) and Co Pant 97222 (T2) and CoPant 84212 (L4) with Co
Pant 97222 (T2) which exhibited the importance of parental selection in the hybridization programmes. Similar types of results are also observed by Anbanandan et al., (2017).

Among the quantitative characters, Germination per cent, Number of Tillers, Number of Millable Cane, Juice Pol Value and Cane Yield showed wide range variation (Tables 4) which provides a wide scope of selection for these characters. Narrow range of variations was observed for Cane Height, Cane Diameter, Brix per cent, Sucrose per cent, Purity per cent, C.C.S. per cent and C.C.S. Yield. These results are in conformity with the observation of Ghosh and Singh (1996), Patel et al., (2006) and Gowda et al., (2016).

The results of the study of CV, GCV and PCV for all the characters are presented in Table 4. Coefficient of variation (CV) was maximum for commercial cane sugar yield (11.222 per cent) followed by cane diameter (10.435 per cent), cane yield (9.561 per cent), single cane weight (9.125 per cent), and cane height (8.202 per cent) and for rest of the traits less than 8 per cent $C V$ was observed.

This suggested that all genotypes were genetically variable and a considerable amount of variability existed among them, therefore, these sugarcane genotypes would respond positively to selection. Deshmukh et al., (1986) categorized GCV and PCV as low ( $<10$ per cent), moderate (10-20per cent) and high (>20per cent). In the present investigation both GCV and PCV estimates were found to be moderate for Germination per cent (10.111 and 12.549). Low GCV and moderate PCV was observed for cane Diameter (6.329 and 12.258), Single cane weight (5.582 and 11.540), CCS per cent (9.222 and 10.851), Cane yield (3.545 and $10.195)$ and CCS yield (9.851 and 14.945). 
Table.2 Analysis of variance (mean squares) for different morphological and quality characters in sugarcane

\begin{tabular}{|c|c|c|c|c|}
\hline S. No. & Characters & \multicolumn{3}{|c|}{ Mean Squares } \\
\hline & & Replication (d.f. $=3$ ) & Treatment (d.f.=13) & Error $($ d.f. $=39)$ \\
\hline 1 & Germination per cent & 8.069 & $44.791 * *$ & 5.309 \\
\hline 2 & Tillers $(000 / \mathrm{h})$ & 9.645 & $227.307 * *$ & 36.020 \\
\hline 3 & NMC (000/h) & 34.962 & $117.319 * *$ & 18.341 \\
\hline 4 & Height & 0.037 & $0.087^{*}$ & 0.041 \\
\hline 5 & Diameter & 0.061 & $0.137 *$ & 0.561 \\
\hline 8 & $\operatorname{Pol}(2015)$ & 29.757 & $111.812 * *$ & 15.438 \\
\hline 9 & Sugar & 1.344 & $5.597 * *$ & 0.793 \\
\hline 10 & Purity per cent & 0.270 & 4.997 & 2.924 \\
\hline 11 & CCS per cent & 0.672 & $4.503 * *$ & 0.397 \\
\hline 12 & Cane yield & 141.687 & $136.437 *$ & 88.282 \\
\hline
\end{tabular}

Table.3 Mean performance of parents and hybrids

\begin{tabular}{|c|c|c|c|c|c|c|c|c|c|c|c|c|c|}
\hline Parent/Hybrid & Germ & Tiller & NMC & Ht & Dia & SCW & Brix & Pol & Sucrose & Purity & C.C.S.\% & CY & C.C.S.Y \\
\hline L1 & 35.29 & 108.94 & 83.09 & 2.61 & 2.22 & 1.23 & 17.46 & 64.58 & 15.65 & 89.91 & 11.53 & 100.26 & 11.53 \\
\hline L2 & 29.78 & 112.53 & 84.28 & 2.35 & 2.20 & 1.09 & 18.23 & 66.25 & 16.01 & 88.12 & 11.76 & 91.40 & 10.76 \\
\hline $\mathbf{L 3}$ & 31.18 & 125.71 & 91.18 & 2.42 & 2.10 & 1.03 & 18.73 & 70.58 & 17.03 & 91.16 & 11.99 & 93.41 & 11.17 \\
\hline L4 & 32.71 & 113.54 & 76.22 & 2.58 & 2.29 & 1.11 & 16.73 & 59.58 & 14.48 & 86.90 & 9.97 & 91.64 & 9.12 \\
\hline $\mathrm{T1}$ & 33.60 & 114.46 & 82.62 & 2.65 & 2.11 & 1.22 & 19.90 & 72.58 & 17.41 & 87.98 & 12.54 & 100.79 & 12.56 \\
\hline T2 & 35.48 & 121.84 & 95.52 & 2.73 & 2.79 & 1.39 & 20.81 & 74.25 & 17.77 & 87.04 & 13.15 & 112.60 & 13.45 \\
\hline L1XT1 & 34.41 & 127.05 & 87.48 & 2.23 & 2.46 & 1.29 & 15.66 & 56.63 & 13.86 & 88.49 & 9.59 & 103.13 & 9.78 \\
\hline L1XT2 & 30.02 & 124.52 & 92.94 & 2.55 & 2.33 & 1.17 & 16.99 & 61.21 & 14.90 & 87.78 & 10.26 & 104.56 & 10.72 \\
\hline L2XT1 & 24.21 & 103.28 & 77.18 & 2.45 & 2.29 & 1.23 & 16.35 & 59.73 & 14.58 & 89.17 & 10.12 & 92.40 & 9.36 \\
\hline L2XT2 & 33.48 & 119.47 & 85.07 & 2.49 & 2.25 & 1.16 & 16.74 & 61.08 & 14.88 & 88.49 & 10.32 & 97.09 & 10.04 \\
\hline L3XT1 & 30.07 & 121.18 & 84.24 & 2.63 & 2.30 & 1.20 & 18.11 & 65.35 & 15.86 & 87.65 & 10.93 & 96.35 & 10.54 \\
\hline L3XT2 & 28.57 & 113.41 & 81.66 & 2.44 & 2.25 & 1.20 & 17.63 & 64.24 & 15.59 & 88.40 & 10.78 & 97.57 & 10.51 \\
\hline L4XT1 & 26.33 & 113.28 & 83.69 & 2.27 & 2.20 & 1.15 & 16.17 & 59.28 & 14.43 & 89.13 & 10.03 & 95.30 & 9.56 \\
\hline L4XT2 & 29.42 & 104.57 & 83.57 & 2.37 & 2.02 & 1.10 & 18.10 & 66.38 & 16.06 & 88.52 & 11.12 & 99.22 & 11.06 \\
\hline $\begin{array}{l}\text { Overall } \\
\text { Means }\end{array}$ & 31.04 & 115.98 & 84.92 & 2.48 & 2.27 & 1.18 & 17.68 & 64.41 & 15.61 & 88.48 & 11.02 & 98.27 & 10.72 \\
\hline
\end{tabular}

(Germ- Germination per cent, Tiller- Number of Tillers, N.M.C. - Number of Millable Canes, Ht - Cane Height, Dia - Cane Diameter, SCW- Single cane weight, Purity- Juice Purity per cent, CY- Cane yield, C.C.S.Y - C.C.S. yield) 
Table.4 Variability estimates of genotypes for different characters in sugarcane

\begin{tabular}{|c|c|c|c|c|c|c|c|c|c|c|c|}
\hline S. & Characters & & & CD & CD & CV\% & Coefficis & variation & $\mathrm{H}^{2}{ }_{b}(\%)$ & GA & GA as $\%$ \\
\hline & & Min & $\operatorname{Max}$ & & & & GCV & PCV & & & \\
\hline 1 & Germination \% & 24.21 & 35.48 & 3.295 & 4.412 & 7.423 & 10.111 & 12.549 & 64.913 & 5.209 & 16.781 \\
\hline 2 & Tillers $(000 / \mathrm{h})$ & 103.28 & 127.05 & 8.584 & 11.492 & 5.174 & 5.962 & 7.895 & 57.032 & 10.758 & 9.275 \\
\hline 3 & NMC (000/h) & 77.18 & 95.52 & 6.125 & 8.201 & 5.043 & 5.861 & 7.735 & 57.421 & 7.769 & 9.149 \\
\hline 4 & Height & 2.23 & 2.65 & 0.291 & 0.389 & 8.202 & 4.575 & 9.561 & 22.892 & 0.112 & 4.509 \\
\hline 5 & Diameter & 2.02 & 2.79 & 0.338 & 0.453 & 10.435 & 6.329 & 12.258 & 26.655 & 0.153 & 6.731 \\
\hline 6 & Single cane weight & 1.03 & 1.39 & 0.154 & 0.206 & 9.125 & 5.582 & 11.540 & 23.400 & 0.066 & 5.563 \\
\hline 7 & $\operatorname{Brix}(2015)$ & 15.66 & 20.81 & 1.443 & 1.932 & 5.706 & 7.638 & 9.524 & 64.320 & 2.232 & 12.619 \\
\hline 8 & $\operatorname{Pol}(2015)$ & 56.63 & 74.25 & 5.619 & 7.524 & 6.101 & 7.621 & 9.757 & 61.010 & 7.898 & 12.263 \\
\hline 9 & Sugar & 13.86 & 17.77 & 1.274 & 1.705 & 5.708 & 7.017 & 9.030 & 60.389 & 1.753 & 11.233 \\
\hline 10 & Purity \% & 86.90 & 91.16 & 2.446 & 3.274 & 1.932 & 0.826 & 2.099 & 15.485 & 0.592 & 0.669 \\
\hline 11 & $\mathrm{CCS} \%$ & 9.59 & 13.15 & 0.901 & 1.206 & 5.725 & 9.222 & 10.851 & 72.227 & 1.778 & 16.145 \\
\hline 12 & Cane yield & 91.40 & 112.60 & 13.438 & 17.990 & 9.561 & 3.545 & 10.195 & 12.091 & 2.495 & 2.539 \\
\hline 13 & CCS yield & 9.12 & 13.45 & 1.721 & 2.304 & 11.222 & 9.851 & 14.945 & 43.449 & 1.435 & 13.377 \\
\hline
\end{tabular}


Table.1 List of all the genotypes used in experiment

\begin{tabular}{|l|l|}
\hline S. No. & Genotypes \\
\hline 1 & Parents \\
\hline 2 & Co Pant 94213 (L1) \\
Co Pant 99213 (L2) \\
\hline 3 & Co Pant 98224 (L3) \\
\hline 4 & CoPant 84212 (L4) \\
\hline 5 & CoSe 92423 (T1) \\
\hline 6 & Co Pant 97222 (T2) \\
\hline & Crosses \\
\hline 1 & Co Pant 94213 X CoSe 92423 (L1XT1) \\
\hline 2 & Co Pant 94213 X Co Pant 97222 (L1XT2) \\
\hline 3 & Co Pant 99213 X CoSe 92423 (L2XT1) \\
\hline 4 & Co Pant 99213 X Co Pant 97222 (L2XT2) \\
\hline 5 & Co Pant 98224 X CoSe 92423 (L3XT1) \\
\hline 6 & Co Pant 98224 X Co Pant 97222 (L3XT2) \\
\hline 7 & Co Pant 84212 X CoSe 92423 (L4XT1) \\
\hline 8 & Co Pant 84212 X Co Pant 97222 (L4XT2) \\
\hline
\end{tabular}

Low genotypic and phenotypic coefficient of variations was observed for the characters viz., Tillers (5.962 and 7.895), number of millable canes (5.861 and 7.735), cane height (4.575 and 9.561), brix per cent (7.638 and 9.524), polarity value (7.621 and 9.757) sucrose content (7.017 and 9.030) and purity per cent $(0.826$ and 2.099). These results indicate the presence of limited genetic variability for these characters. These findings are found similar with Singh et al., (1983), Ghosh and Singh, (1996) and Gowda et al., (2016).

For effective selection of superior genotypes presence of variability is a pre-requisite and it is both nature and magnitude of genotypic variability which decide progress of a breeding programme. In the present study PCV were found higher than GCV for all characters but the closeness between GCV and PCV values for Germination per cent, number of tillers, number of millable canes, brix per cent, polarity value, sucrose content, purity per cent, commercial cane sugar per cent and commercial cane sugar yield indicating them to be less influenced by environment. Similar results are also observed by Sanghera et al., (2014). Therefore, it may be concluded that selection can be employed in the desired direction on the basis of phenotype to improve those characters in sugarcane.

The estimates of heritability in broad sense $\left(\mathrm{h}^{2} \mathrm{~b}\right)$ exhibited considerable variation for various traits and also presented in Table 2. None of the traits exhibited high heritability $(\geq 75$ per cent) and moderate heritability (50$75 \%$ ) was observed for commercial cane sugar per cent $(72.227 \%)$, followed by Germination per cent (64.913per cent), Brix per cent (64.320per cent), Pol Value $(61.010 \%)$, sucrose content (60.389), number of millable canes $(57.421 \%)$ and number of tillers (57.032per cent). All the remaining traits viz., commercial cane sugar yield $(43.449 \%)$, cane diameter $(26.655 \%)$, Single cane weight $(23.400 \%)$, cane height $(22.892 \%)$, purity per cent (15.485per cent) 
and cane yield $(12.091 \%)$ showed low values of heritability $(\leq 50 \%)$. The moderate heritability magnitude was observed for commercial cane Sucrose per cent germination per cent, brix per cent, number of tillers, sucrose content, number of millable canes and polarity value For rest of the traits, since the heritability is low, these traits are difficult to improve. These results are in agreement with the earlier results by Sanghera et al., (2014) and Mali and Patel (2013).

Genetic advance as per cent of mean (GAM) exhibited considerable variation for different characters. Deshmukh et al., (1986) classified genetic advance as per cent of mean as low $(<10 \%)$, moderate $(10-20 \%)$ and high $(>20 \%)$. None of the traits exhibited higher values of genetic advance as per cent of mean but moderate values were observed for germination per cent $(16.781 \%)$, commercial cane sugar per cent $(16.145 \%)$, commercial cane sugar yield (13.377\%), brix per cent $(12.619 \%)$, polarity value $(12.263 \%)$ and sucrose content (11.233\%). Low genetic advance as per cent mean was observed for number of tillers $(9.275 \%)$, number of millable canes $(9.149 \%)$, cane diameter $(6.731 \%)$, single cane weight $(5.563 \%)$, cane height $(4.509 \%)$, cane yield $(2.539 \%)$ and purity per cent $(0.669 \%)$.

The heritability estimates are more useful when expressed in terms of genetic advance. Moderate heritability with moderate values of genetic advance as per cent mean were reported for germination per cent, brix per cent, polarity value, sucrose content and commercial cane sugar per cent. These characters show additive gene action and improvement through direct selection could be possible for these characters. Low heritability with moderate genetic advance as per cent mean was found for commercial cane sugar yield whereas, moderate heritability coupled with low genetic advance was observed for number of tillers and number of millable canes. Pandey (1989) had earlier reported the low genetic advance with moderate amount of heritability for stalk diameter suggesting a little scope in the improvement of this character. Low heritability coupled with low genetic advance was found for cane height, cane diameter, single cane weight, purity per cent and cane yield and this indicate that these traits were highly influenced by environment and selection would be ineffective for these characters.

From the present study it can be concluded that genetic variability exists among the studied genotypes for all the traits. There was closeness between GCV and PCV values for Germination Per cent, commercial cane sugar per cent and commercial cane sugar yield indicate that these traits were less influenced by environment. Moderate heritability coupled with moderate genetic advance reported in characters for germination per cent, brix per cent, polarity value, sucrose content and commercial cane sugar per cent. Hence, improvement through direct selection could be possible for these characters. Based on mean performance Co Pant 97222 (T2) and Co Pant 98224 (L3) could be considered as desirable parents to use in hybridization programmes to improve sugarcane yield.

\section{References}

Alarmelu S, Hemaprabha G, Nagarajan R and Shanthi R M (2010) Combining ability for yield and quality in Sugarcane. Electronic Journal of Plant Breeding. 1(4): 742-746.

Allard, R.W.1960. Principles of Plant Breeding. John Wiley and Sons, Inc. New York, pp. 138-142.

Anbanandan, V., Eswaran, R. and Sabesan, T. 2017. 'Heterosis In Interspecific And Intergeneric Progenies Of Sugarcane' 
Life Sciences International Research Journal, 4(1): 43-46.

Deshmukh, S.N.; Basu, M.S. and Reddy, P.S. 1986. Genetic variability, character association and path coefficient analysis of quantitative traits in Virginia bunch varieties of groundnut. Indian Journal of Agricultural Science, 56(1): 816-821.

Falconer, D.S., and Trudy, F.C.M. 1996. Introduction to Quantitative Genetics $4^{\text {th }}$ ed. Longman Group Limited. Malaysia, $450 \mathrm{p}$.

Ghosh, J. and Singh, J. R. P. (1996). Variability in early maturity clones of sugarcane. Cooperative sugar, 27(5): $341-345$.

Gomez, K. A. and Gomez, A. A. 1984. Statistical Procedures for Agricultural Research. $2^{\text {nd }}$ Edn. A Wiley-Interscience Publication, New York.

Gowda, S.N.S., Saravanan, K. and Ravishankar, C.R. 2016. Genetic variability, heritability and genetic advance in selected clones of sugarcane. Plant Archives, 16(2): 700-704.

Hamdi, A.1992. Heritability and combining ability of root characters in lentil (Lens culinaris Medik). Egyptian Journal of Agricultural Research, 70(1): 247-255.

Hayman, B.I. 1958. The theory and analysis of diallel crosses. II. Genetics. 43, pp 63 -65 .

India. Ministry of Agriculture and Farmers Welfare, Department of Agriculture, Cooperation and Farmers Welfare. 2016. Agriculture Statistics at a Glance. Delhi. Controller of Publication. 489p

Johnson, H.W., Robinson, H.F., and Comstock, R.E. 1955. Estimation of genetic and environmental variability in soybeans. Agronomy Journal, 47(7): 314-318.

Katiyar, R.P. 1979. Heterosis in relation to per-se performance and effects of general combining ability in chickpea. Indian J. Agric. Sci., 49(5): 313-7.
Krishnamurthi. Wide hybridization and exploitation of heterosis in sugarcane (Saccharum officinarum L.). In: National Seminar on hybrid breeding in crop plants held on 3-4 March, 2004 at Annamalai University, Annamalainagar, India.

Loganathan, P., Saravanan K. and Ganesan, J. 2001. Heterosis for yield and yield components in greengram. Legume Res., 24: 77-81.

Mali, S.C. and Patel, A.I. 2013. Correlation and heritability studies in sugarcane. AGRES - An International e-Journal, 2(4): 466-471.

Nadaraja. 1986. Genetic analysis of fibre characters in cotton (Gossypium hirsutum L.). Ph.D. Thesis Tamil Nadu Agrl. Univ., Coimbatore, India.

Pandey, R.A. 1989. Variability study in the hybrid progenies of sugarcane (Saccharum complex). Bhartiya Sugar (Oct.): 49-51.

Patel, K.C., Patel, A.I.; Mali, S.C.; Patel, D.U. and Vashi R.D. 2006. Variability, correlation and path analysis in sugarcane (Saccharum spp.). Crop Res., 32(2): 213-218.

Patil, P.P. and Patel, D.U. 2017. Study of Genetic Variability and Heritability in Sugarcane. International Journal of Current Microbiology and Applied Sciences, 6(9): 3112-3117.

Prince, S. 1963. Cytogenetics of modern sugarcanes. Econ. Bot. 17: 97- 106.

Rajeswari, S., V. Anbanandan, K. Shanmugasundaram, S Thirugnanakumar and M. Sanghera, G.S., Tyagi, V., Kumar, R. and Thind, K. S. 2014. Genetic variability for cane yield, earliness and quality traits in sugarcane under subtropical region of india. International Journal of Current Research. 6(8): 7763-7765.

Singh, H. N., Singh, S.B., Chauhan, R.V.S. and Vishwakarma, R.S. 1983. 
Variability for yield and quality in sugarcane. Indian J. Agric. Sci., 53: 786-789.

Singh, M., Mishra, D.K., Shukla, R.S., and Samaiya, R.K. 2015. Variation and heritability for some quality characteristics and grain yield in bread wheat (Triticuma estivum L.). Trends in Biosciences, 8(1): 68-70.

Singh, R.K., and Chaudhary, B.D. 1985. Biometrical Methods in Quantitative Analysis. Kalayani Publishers. New Delhi.
Tyagi, A. P. and Lal, P. 2005. 'Line $\mathrm{x}$ tester analysis in sugarcane (Saccharum officinarum)', The South Pacific Journal of Natural Science, 23: 30-36.

Tyagi, S.D., and Singh, D.N. 1998. Studies on genetic variability for stalk characters in sugarcane. Indian Sugar XL VIII: 259262.

Verma, P.S. 1990. Heterosis in sugarcane. Indian J. Genet., 50(2): 117-120.

Yang, T.C. and Chu, C.C. 1962. Evaluation of combining ability in sugarcane (Part-1) report of Taiwan. Sug. Exp. Sta., 26: 110.

\section{How to cite this article:}

Deepankar Pandey, S.P. Singh, A.S. Jeena, K. A. Khan, Tabassum, Arvind Negi and Deepak Koujalagi. 2018. Study of Genetic Variability, Heritability and Genetic Advance for Various Yield and Quality Traits in Sugarcane Genotypes (Saccharum officinarum). Int.J.Curr.Microbiol.App.Sci. 7(04): 1464-1472. doi: https://doi.org/10.20546/ijcmas.2018.704.165 